\title{
Cost Effective Use of a Thiosulfinate-Enriched Allium sativum Extract in Combination with Chemotherapy in Colon Cancer
}

\author{
Jose Manuel Perez-Ortiz ${ }^{1,2}, * \mathbb{E}$, Eva Maria Galan-Moya ${ }^{1,3}$, , Miguel Angel de la Cruz-Morcillo ${ }^{1}$, \\ Juan Francisco Rodriguez ${ }^{4}{ }^{\circ}$, Ignacio Gracia ${ }^{4}$, Maria Teresa Garcia ${ }^{4}(\mathbb{})$ and \\ Francisco Javier Redondo-Calvo ${ }^{1,2,5}$ \\ 1 Translational Research Unit, Hospital General Universitario de Ciudad Real, 13004 Ciudad Real, Spain; \\ EvaMaria.Galan@uclm.es (E.M.G.-M.); sabesdemas@gmail.com (M.A.d.l.C.-M.); \\ fjredondo@sescam.jccm.es (F.J.R.-C.) \\ 2 Department of Medical Sciences, School of Medicine, Universidad de Castilla-La Mancha, \\ 13071 Ciudad Real, Spain \\ 3 Translational Oncology Laboratory, Centro Regional de Investigaciones Biomédicas (CRIB), Universidad de \\ Castilla-La Mancha, 02008 Albacete, Spain \\ 4 Department of Chemical Engineering, Institute of Chemical and Environmental Technology, Universidad de \\ Castilla-La Mancha, 13071 Ciudad Real, Spain; Juan.RRomero@uclm.es (J.F.R.); \\ Ignacio.Gracia@uclm.es (I.G.); teresa.garcia@uclm.es (M.T.G.) \\ 5 Department of Anesthesiology, Hospital General Universitario de Ciudad Real, 13004 Ciudad Real, Spain \\ * Correspondence: jmperezo@sescam.jccm.es; Tel.: +34-926278000 (ext. 79111)
}

Received: 8 March 2020; Accepted: 14 April 2020; Published: 16 April 2020

\begin{abstract}
In this work, we sought to investigate the effects of a thiosulfinate-enriched garlic extract, co-administered with 5-fluorouracil (5-FU) or oxaliplatin chemotherapy, on the viability of colon cancer cells (Caco-2 and HT-29). We also addressed the economic feasibility of a new combined treatment of this thiosulfinate-enriched garlic extract, with oxaliplatin that could reduce the dosage and costs of a monotherapy. The thiosulfinate-enriched garlic extract not only enhanced the impact of 5-FU and oxaliplatin $(500 \mu \mathrm{M})$ in decreasing Caco-2 and HT-29 viability, but also showed a higher effect than standard 5-FU and oxaliplatin chemotherapy as anti-cancer agents. These results provided evidences for the combination of lyophilized garlic extract and 5-FU or oxaliplatin as a novel chemotherapy regimen in colon cancer cells that may also reduce the clinical therapy costs.
\end{abstract}

Keywords: thiosulfinate; garlic; allicin; HT-29; Caco-2; chemotherapy

\section{Introduction}

Today, the use of natural sources instead of chemical derivatives in pharmaceutical industry is a development sector within the "Biorefinery" concept worldwide [1]. Structural diversity is a striking feature of natural products (NPs), accounting for their lasting importance in drug discovery [2-4]. In addition, most NPs show more favorable behavior compared to synthetic molecules, due to their biological properties. Moreover, they can be easily tailored, modified or blended for new drug targets [5].

One of the most cited NP for pharmacological applications during the last years is garlic (Allium sativum) and its derivatives. The therapeutic properties of garlic have been known, researched and used for more than 5000 years by different cultures, both for the treatment and prophylaxis of a great number of pathologies [6]. Among the properties that have been attributed to garlic throughout the history, it has been highlighted its antitumoral, immunomodulatory, antioxidant, bacteriostatic, 
anti-inflammatory, antiviral, antiparasitic and bactericidal capacities [7]. Therefore, garlic and its bioactive compounds are promising as functional foods or nutraceuticals for the prevention and treatment of different diseases [8].

In general, the therapeutic use of garlic has taken as reference the properties that have been attributed to allicin in most of the studies carried out [9]. In contrast, the instability of this compound has led to several researchers to focus on the properties of other compounds derived from allicin such as ajoene [10], which has demonstrated longer stability and more manageable presentations (U.S. Patent No. 5948821; U.S. Patent No. 5981602). Other groups have been involved in the synthetic preparation of allicin from alliinase and alliin, the precursor of allicin, whose in situ generation and application in tumor cells in vitro has demonstrated an antiproliferative effect (U.S. Patent No. 6689588). However, there are some studies that claim that synthetic allicin is more unstable than natural allicin [11], and that the natural alliinase from garlic chemically differs from that obtained from processed garlic, such as can be detected in natural garlic or even dehydrated garlic [12]. On the other hand, it has been demonstrated that isolated natural allicin generates a less relevant bacteriostatic effect than when it acts in conjunction with other garlic compounds, such as allyl substituted thiosulfinates $[13,14]$, suggesting a synergistic effect of the compounds present in garlic.

Due to a generalized lack of chemical stability [15], standardization in production processes [16] and chemical characterization in clinical studies [17], research based on the use of garlic derivatives has led to ambiguous conclusions about the beneficial effects of these derivatives, thus preventing the application of garlic products in the treatment of diseases [18]. Therefore, it still remains a need to provide a standard procedure for the preparation of stable garlic-derived compositions which can be used in clinical or biological trials in order to objectively determine the properties attributable to this NP depending on their total or partial composition.

To avoid most of the problems previously cited, we employed a thiosulfinate-enriched Allium sativum extract obtained by a standardized patented protocol from a purple garlic variety from Las Pedroñeras (Spain), the only European region with a protected geographical indication for garlic. We aim to validate, from both experimental and economic points of view, the use of a thiosulfinate-enriched Allium sativum extract as a source of active principles to pharmacological approaches. In particular, we aim to provide an evidence for the use of this new lyophilized garlic extract as a coadjuvant for chemotherapy drugs to increase their activity in treating colorectal tumors and to analyze the economic savings that a combined therapy could offer.

\section{Results}

\subsection{The Thiosulfinate-Enriched Allium sativum Extract Decreased Viability and Increased Cytotoxicity in Colon Cancer Cells}

As mentioned in the Material and Methods section, we used allicin content to refer the dosage of the thiosulfinate-enriched Allium sativum extract that we employed in this work. The full list of organic and inorganic compounds contained in the garlic derivate used in this study is presented in Table 1.

First, we tested the effect of the thiosulfinate-enriched Allium sativum extract on colon cancer cell viability. For this purpose, Caco-2 and HT-29 cells were exposed to increasing doses of the thiosulfinate-enriched Allium sativum extract, measured as increasing concentrations of allicin. A clear reduction in cell viability was observed with all the methods used. Neutral red assay revealed a marked decrease in cell viability ( $\geq 70 \%$ ) in Allium sativum extract-treated cells (from $75 \mu \mathrm{g} / \mathrm{mL}$ allicin), after just $24 \mathrm{~h}$ of incubation (Figure 1). 
Table 1. Composition of the thiosulfinate-enriched Allium sativum extract. List of organic and inorganic compounds present in the lyophilized Allium sativum extract from Las Pedroñeras (Ciudad Real, Spain), under optimized conditions.

\begin{tabular}{|c|c|c|c|}
\hline Compound & Concentration $(\mu \mathrm{g} / \mathrm{mg})$ & Compound & Concentration $(\mu \mathrm{g} / \mathrm{mg})$ \\
\hline Allyl-1-propenyl thiosulfinate & 31.023 & K & 3974.85 \\
\hline Dimethyl thiosulfinate & 18.302 & $\mathrm{Si}$ & 3665.76 \\
\hline Dimethyl tetrasulfide & 6.619 & $\mathrm{P}$ & 1188.87 \\
\hline Diallyl thiosulfinate (allicin) & 5.617 & $\mathrm{Cu}$ & 298.16 \\
\hline Prostaglandin E1 & 4.831 & $\mathrm{Mg}$ & 188.41 \\
\hline Methyl allyl disulfide & 4.725 & $\mathrm{Ca}$ & 159.12 \\
\hline $\begin{array}{l}\text { Allylmethyl + Methyl-allyl } \\
\text { thiosulfinate }\end{array}$ & 4.581 & $\mathrm{Na}$ & 102.41 \\
\hline Methyl allyl sulphide & 3.575 & $\mathrm{Fe}$ & 95.84 \\
\hline $\begin{array}{l}\text { Propyl-methyl + Methyl-propyl } \\
\text { thiosulfinate }\end{array}$ & 3.394 & B & 89.45 \\
\hline Vitamin E ( $\alpha$-tocopherol) & 3.072 & $\mathrm{Cr}$ & 26.37 \\
\hline $\begin{array}{l}\text { 1-propenyl-allyl + allyl-propyl } \\
\text { thiosulfinate }\end{array}$ & 1.760 & $\mathrm{Zn}$ & 10.60 \\
\hline Di-propyl thiosulfinate & 1.653 & $\mathrm{Cd}$ & 9.48 \\
\hline Di-methyl pentasulfide & 1.631 & Se & 9.37 \\
\hline Propyl-allyl thiosulfinate & 1.591 & $\mathrm{Mn}$ & 1.18 \\
\hline Di-allyl trisulfide & 0.736 & $\mathrm{Co}, \mathrm{Hg}$ & Non Detected \\
\hline Inulin & 0.103 & $\mathrm{Al}$ & Non Detected \\
\hline (E,Z)-Ajoene & 0.068 & $\mathrm{Ni}$ & Non Detected \\
\hline
\end{tabular}

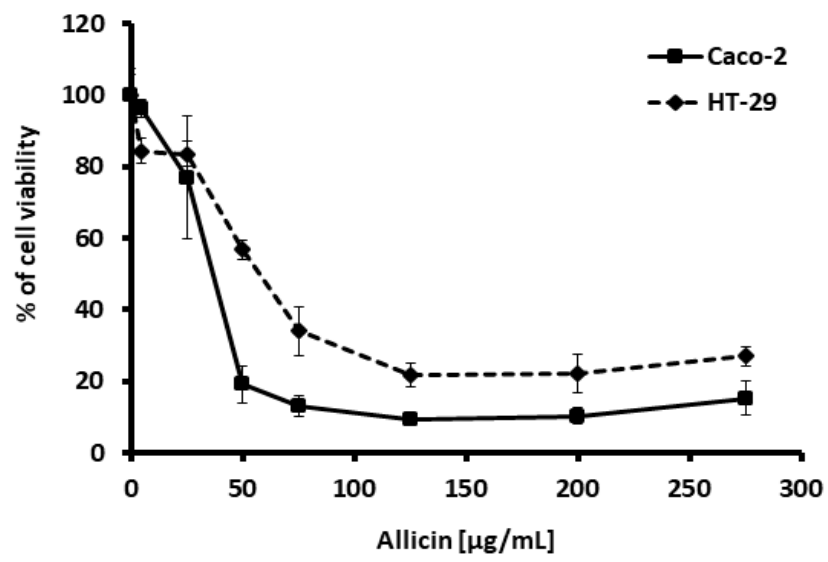

Figure 1. Effect of various thiosulfinate-enriched Allium sativum extract concentrations on cell viability of the colon cancer cell lines Caco-2 and HT-29, after $24 \mathrm{~h}$ incubation. Neutral red assays were performed, and the percentage of viable cells was calculated. Values represent means of six replicates \pm SD of one representative experiment.

Similarly, MTT assays showed a 60-80\% cell demise in response to the thiosulfinate-enriched Allium sativum extract (from $100 \mu \mathrm{g} / \mathrm{mL}$ allicin) (Figure 2), using the same dose-response approach. 


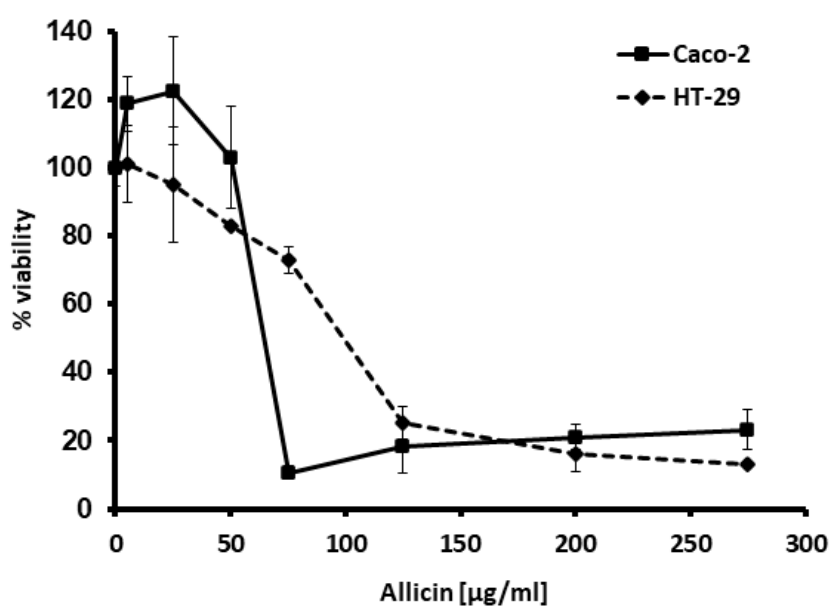

Figure 2. Effect of various thiosulfinate-enriched Allium sativum extract concentrations on cell viability of the colon cancer cell lines Caco-2 and HT-29, after $24 \mathrm{~h}$ incubation. MTT assays were performed, and the percentage of viable cells was calculated. Values represent means of six replicates \pm SD of one representative experiment.

This effect on cell viability impairment, due to increasing concentrations of the thiosulfinate-enriched Allium sativum extract, was further confirmed by the morphological observation under the microscope of HT-29, as shown in Supplementary Figure S1. Thus, the incubation for $24 \mathrm{~h}$ with increasing concentrations of allicin $(2.5 ; 5 ; 10 ; 25 ; 50 ; 75$ and $100 \mu \mathrm{g} / \mathrm{mL})$ elicited the appearance of rounded and detached cells, typical symptoms of affected cells in culture. In fact, the damage produced by the thiosulfinate-enriched Allium sativum extract was much more pronounced and according to what was observed in the previous tests of cellular viability with increasing concentrations of allicin.

Moreover, we further explored cell damage and cytotoxicity due to the thiosulfinate-enriched Allium sativum extract incubation with Caco-2 and HT-29. LDH release, a signal of cell membrane impairment, which occurs when cell integrity is compromised, was also detected in the supernatants after $24 \mathrm{~h}$ incubation with different concentrations of the thiosulfinate-enriched Allium sativum extract, as seen in Figure 3. All these results point out that the thiosulfinate-enriched Allium sativum extract can affect colon cancer cells survival in vitro and in a short period of time.

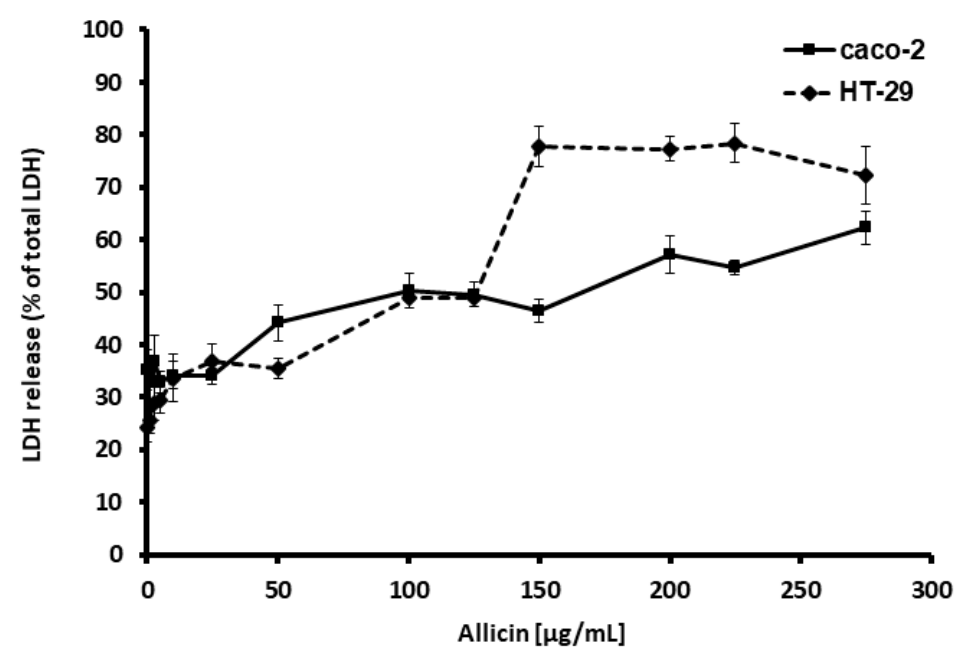

Figure 3. Cytotoxic effect of thiosulfinate-enriched Allium sativum extract on Caco-2 and HT-29 cells by the $\mathrm{LDH}$ test, after $24 \mathrm{~h}$ incubation. Concentrations are expressed as $\mu \mathrm{g} / \mathrm{mL}$ of allicin. Values represent means of 6 replicates \pm SD of one representative experiment. 


\subsection{Analyses of the Type of Death Induced by the Thiosulfinate-Enriched Allium sativum Extract Treatment}

In order to examine the type of cell death triggered by the garlic compound, we determined the amount of viable, apoptotic and necrotic cells after $24 \mathrm{~h}$ incubation with different thiosulfinate-enriched Allium sativum extract concentrations. We assessed apoptosis by the TUNEL method on HT-29 cells. As indicated in Table 2, we assessed a rapid decrease in cell viability, with increasing concentrations of the thiosulfinate-enriched Allium sativum extract (referred to as allicin), in terms of a higher percentage of early apoptotic cells. A significant increase in necrotic cells was not found.

Table 2. Analysis of type of death. Percentage of viable, apoptotic (early and late) and necrotic cells after $24 \mathrm{~h}$ incubation, with increasing concentrations of the thiosulfinate-enriched Allium sativum extract $(10,50$ or $100 \mu \mathrm{g} / \mathrm{mL}$ allicin).

\begin{tabular}{ccccc}
\hline & Control & Allicin $[\mathbf{1 0} \mu \mathrm{g} / \mathrm{mL}]$ & Allicin $[\mathbf{5 0} \boldsymbol{\mu g} / \mathrm{mL}]$ & Allicin $[\mathbf{1 0 0} \boldsymbol{\mu g} / \mathrm{mL}]$ \\
\hline Viable cells & $98.40 \%$ & $94.20 \%$ & $74.50 \%$ & $54.12 \%$ \\
\hline Early apoptotic cells & $0.31 \%$ & $4.53 \%$ & $22.24 \%$ & $44.04 \%$ \\
\hline Late apoptotic cells & $0.16 \%$ & $0.16 \%$ & $0.26 \%$ & $1.43 \%$ \\
\hline Necrotic cells & $1.09 \%$ & $1.11 \%$ & $3 \%$ & $2.41 \%$ \\
\hline
\end{tabular}

\subsection{Combination of the Thiosulfinate-Enriched Allium sativum Extract with Chemotherapy Drugs}

After that, we explored whether the thiosulfinate-enriched Allium sativum extract could function as a coadjuvant in chemotherapy treatments, so we established a pattern of combined administrations $(0,5,50$ and $200 \mu \mathrm{g} / \mathrm{mL}$; referred to allicin content), with three different concentrations of 5-fluorouracil (5-FU) or oxaliplatin $(5,50$ and $500 \mu \mathrm{M})$. After $24 \mathrm{~h}$ incubation, the MTT assay revealed that, when combined with $500 \mu \mathrm{M} 5-\mathrm{FU}, 50 \mu \mathrm{g} / \mathrm{mL}$ of thiosulfinate-enriched Allium sativum extract enhanced the cell toxicity effects of 5-FU significantly, both in Caco-2 $(-20 \%)$ and HT-29 $(-66 \%)$. Moreover, 10 and $50 \mu \mathrm{g} / \mathrm{mL}$ of thiosulfinate-enriched Allium sativum extract plus $500 \mu \mathrm{M}$ oxaliplatin were more potent at decreasing viability in Caco-2 $(-22 \%$ and $-60 \%$, respectively) and HT-29 $(-48 \%$ and $-67 \%$, respectively) cells, compared to $500 \mu \mathrm{M}$ oxaliplatin alone (Figure 4). Results showed that combinations entailing the thiosulfinate-enriched Allium sativum extract and chemotherapy (5-FU/oxaliplatin) were able to reduce $\geq 20 \%$ cell viability (indicated by a dashed line in Figure 4 ) and were also statistically significant when compared to allicin or the chemotherapy drugs alone (indicated by an asterisk in Figure 4). This could be valuable to increase 5-FU/oxaliplatin efficacy or to avoid higher doses of 5-FU/oxaliplatin to get the same level of impairment.

\subsection{Cost Effectiveness of Treatments Combining the Thiosulfinate-Enriched Allium sativum Extract with Chemotherapy}

This part of the work aims to evaluate the costs associated to a chemotherapy treatment for both, standard oxaliplatin and alternative combination of oxaliplatin plus thiosulfinate-enriched Allium sativum extract and to determine the economic savings that could be derived from the use of combined therapy. This study was performed on the following basis: a standard patient (in terms of age and body weight) with advanced colorectal cancer undergoing 12 cycles of chemotherapy over 6 months, and receiving $85 \mathrm{mg} / \mathrm{m}^{2}$ of oxalipaltin in each cycle, according to actual treatment guides (National Comprehensive Cancer Network Guidelines for Treatment of Colon Cancer, 2019).

- $\quad$ Standard oxaliplatin dosage: $85 \mathrm{mg} / \mathrm{m}^{2}$ per cycle (equivalent to $1000 \mu \mathrm{M}$ oxaliplatin)

- $\quad$ Patient dosing surface: $1.7 \mathrm{~m}^{2}$

- $\quad$ Number of chemotherapy cycles: 12

- $\quad$ Cost of commercial oxaliplatin vial ( $5 \mathrm{mg} / \mathrm{mL}, 20 \mathrm{~mL}$ ): $132.26 €$ (including 4\% VAT) 
These data required approximately a total of 18 vials $(5 \mathrm{mg} / \mathrm{mL}, 20 \mathrm{~mL}) \times / 132.26 €$, giving a cost of $2380.68 €$ for standard treatment.

The combined chemotherapy treatment was based on the following data, and calculated considering previous results for equivalent dosages that produced a similar cytotoxic effect (i.e., $500 \mu \mathrm{M}$ oxaliplatin $+50 \mu \mathrm{g} / \mathrm{mL}$ allicin vs. $1000 \mu \mathrm{M}$ oxaliplatin; data not shown):

- Combined oxaliplatin dosage: $42.5 \mathrm{mg} / \mathrm{m}^{2}$ per cycle (equivalent to $500 \mu \mathrm{M}$ oxaliplatin)

- $\quad$ Combined thiosulfinate-enriched Allium sativum extract (Aliben@) dosage: $2.67 \mathrm{~g}$ per cycle (equivalent to $50 \mu \mathrm{g} / \mathrm{mL}$ allicin)

- $\quad$ Patient dosing surface: $1.7 \mathrm{~m}^{2}$

- $\quad$ Number of chemotherapy cycles: 12

- $\quad$ Cost of commercial oxaliplatin vial $(5 \mathrm{mg} / \mathrm{mL}, 20 \mathrm{~mL}): 132.26 €$ (including $4 \%$ VAT)

- $\quad$ Cost of commercial Aliben@): $5 € / g$, including 4\% VAT (1 g of Aliben $@$ contains $7.030 \mathrm{mg}$ of allicin)

The combined treatment requires an approximate total of nine vials of oxaliplatin $(5 \mathrm{mg} / \mathrm{mL}$, $20 \mathrm{~mL}, 132.26 €$ each vial) and $32 \mathrm{~g}$ of Aliben (C) to achieve a dosage of $500 \mu \mathrm{M}$ oxaliplatin $+50 \mu \mathrm{g} / \mathrm{mL}$ allicin in each cycle. This alternative treatment costs $1350.34 €$. These results show that, on the same cellular impairment level, combined treatment might reduce the cost by $43.3 \%$.

\section{Caco-2}
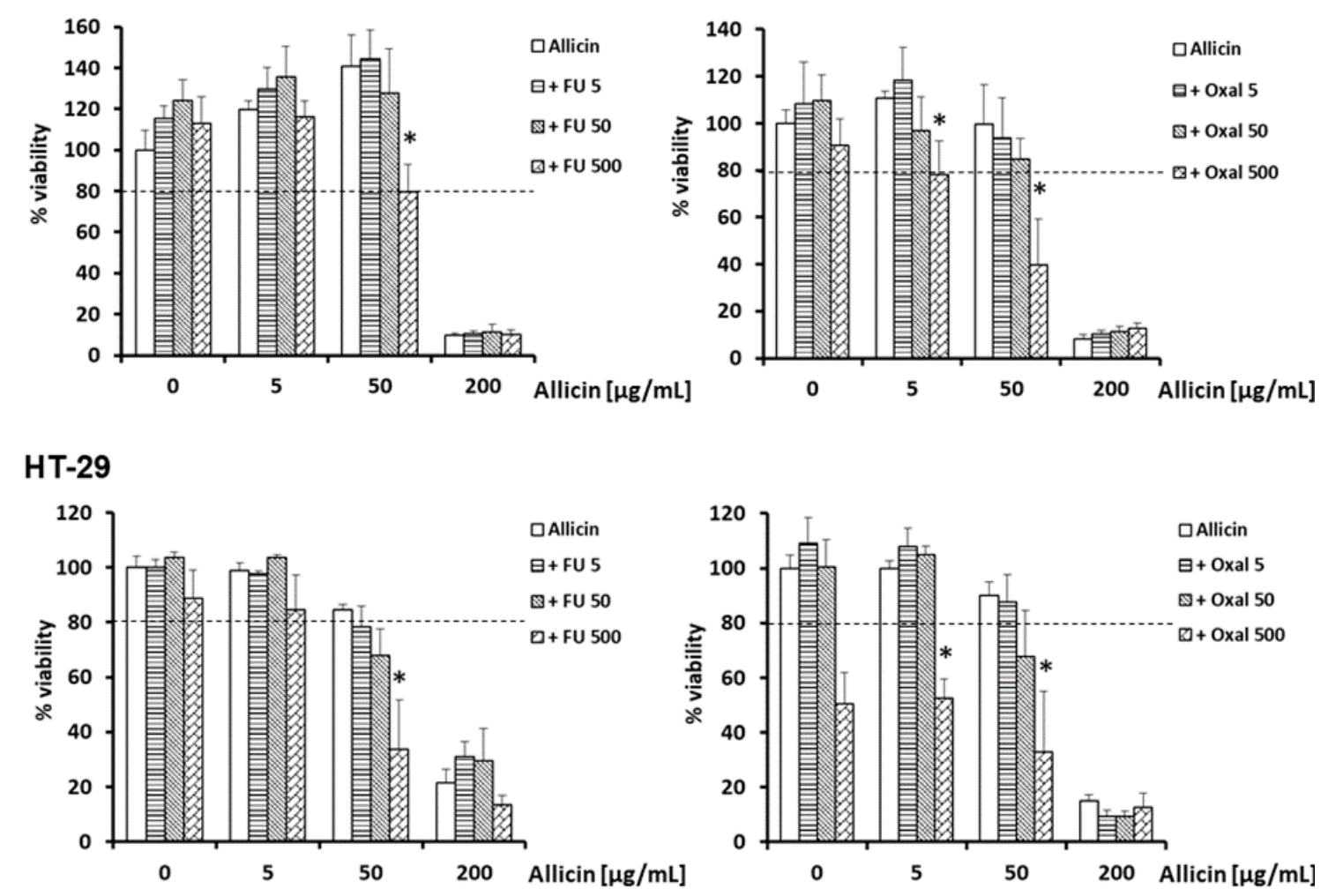

Figure 4. Effect of various Allium sativum extract concentrations $(0,5,50$ and $200 \mu \mathrm{g} / \mathrm{mL}$; referred to allicin content, OX axis) with 5-FU or oxaliplatin $(5,50$ and $500 \mu \mathrm{M})$ on cell viability of the colon cancer cell lines Caco-2 and HT-29, after 24h incubation. MTT assays were performed, and the percentage of viable cells was calculated. Values represent means of 6 replicates \pm SD of one representative experiment. ${ }^{*} p<0.05$ respect to its corresponding allicin or drug group.

The total number of new invasive cancer cases in 2015 in Spain was 247,771 (148,827 in men and 98,944 in women), the most common being colon-rectum cancer, with 41,441 new cases [19]. Taking into account that $50 \%$ of colon cancer patients would be treated with chemotherapy, the combined 
alternative treatment using a thiosulfinate-enriched Allium sativum from Aliben $\bigodot$ could provide 21.35 million $€$ savings per year to the Public Spanish Health System.

\section{Discussion}

In this work, we presented a novel standardized and lyophilized garlic extract (thiosulfinate-enriched), suitable for pharmacological testing and with potent anticarcinogenic effects. Importantly, this extract was obtained by a patented protocol from a purple garlic variety, which is stable for more than 10 months when stored at $4{ }^{\circ} \mathrm{C}$ (WO 2008/102036 A1. Method for obtaining a freeze-dried, stable extract from plants of the Allium genus). This fact enables proper storage and handling over time, compared to other garlic extraction methods. Besides, we provided evidence for the combination of this new lyophilized garlic extract and 5-FU or oxaliplatin as a likely novel chemotherapy treatment for colon cancer cells. This regimen not only proved to be effective in affecting colorectal cancer cells, but also proved to reduce the chemotherapy drug dosage, so that a $43 \%$ reduction in the economic cost of the therapy could be achieved.

We tested the cytotoxic effects of the thiosulfinate-enriched Allium sativum extract in two different human colon cancer cell lines, Caco-2 and HT-29, with similar results in both cell lines for three different cell viability assays (Neutral Red, MTT and LDH). The concentrations of allicin that were found to significantly inhibit the proliferation of colon cancer cells in this study $(43-60 \mu \mathrm{g} / \mathrm{mL}$ allicin, equivalent to $260-360 \mu \mathrm{M}$ ) were similar to those reported in a previous study [20], but lower than others, where concentrations of 80 to $166 \mu \mathrm{g} / \mathrm{mL}$ [21] or even $480 \mu \mathrm{g} / \mathrm{mL}$ [22] were needed to achieve significant inhibition. A possible explanation for the differential efficacy of the garlic extract may be that the allicin contained in the thiosulfinate-enriched Allium sativum extract was obtained in situ (see Table 1) and not, as in the other studies, synthetically from its precursor. This has the advantage of a prolonged integrity of allicin and other thiosulfinates present in Aliben $($ ).

Our data show that allicin is an inhibitor of cell viability and cell proliferation in a concentration dependent manner, something that has been well established to date by a number of works dealing with its anticarcinogenic and antitumorigenic capabilities [9,20,23-26]. However, the chemical properties of the lyophilized extract used in our work makes it suitable for different pharmacological approaches (i.e., water solution, hydroalcoholic lotion, hydrogel, cream).

Research has revealed that allicin targets multiple pathways implied in the inhibition of cancer development [27], including cell cycle arrest [21,28], the induction of apoptosis [29-34], the induction of histone acetylation [35] and the inhibition of angiogenesis [36]. Some of these studies dealing with the induction of apoptosis by allicin have also been reported for Caco-2 and HT-29 [20,34,37]. In our study, we also confirmed the induction of apoptosis in HT-29 cells incubated with the thiosulfinate-enriched Allium sativum extract for $24 \mathrm{~h}$ (see Table 2).

Because allicin exhibits other pharmacological effects, such as cardiovascular and anti-microbial effects, this compound can be classified as a promiscuous agent [38]. However, if we considered promiscuity as versatility, it may be an advantage for cancer chemotherapeutic agents, because the pathogenesis of cancer is complex, involving abnormalities in multiple checkpoints and signaling pathways. As allicin targets multiple signal transduction pathways, it is also conceivable that this lyophilized garlic extract may prove useful in combination with mechanistically distinct chemotherapeutic agents, such as the ones that we propose. In fact, the use of natural compounds for combinatorial therapy in cancer treatment is a new promising line of research [39-41]. Moreover, because of its pharmacological safety, this garlic extract has been proposed to be used alone to prevent cancer and in combination with chemotherapy to treat cancer [42]. 


\section{Materials and Methods}

\subsection{Thiosulfinate-Enriched Allium satioum Extract}

The garlic extract was obtained following a standardized and patented protocol for the production of a new lyophilized garlic extract (WO 2008/102036 A1), commercially available under the brand name Aliben(C) (Aliben Foods S.L., Ciudad Real, Spain). The procedure was as follows: purple garlic was provided by Coopaman (Las Pedroñeras, Spain). The garlic was used with 1 month of maturation, and it was maintained at $4{ }^{\circ} \mathrm{C}$ from harvesting. The solvents used were ethanol (purity 96\% v/v) and acetone (purity 99.5\%). Other products were hydrochloric acid (purity 37\%), methanol (HPLC-isocratic-preparative) for instrumental analysis and diallyl disulfide (purity 99\%), used as an internal standard and provided by Panreac Quimica (Barcelona, Spain). Ethanol and acetone garlic extractions were obtained in a stirred tank extractor with the conditions optimized in a previous work, to maximize the yield of the process [43], according to the next procedure: extractions were performed by introducing $25 \mathrm{~g}$ of freshly milled garlic into a $1 \mathrm{~L}$ extractor along with $400 \mathrm{~mL}$ of the appropriate solvent (ethanol and acetone). The stirring system consisted of a jar-test Vittadini 6-P model Isco (Rome, Italy), with digital control of the stirring speed and set at $175 \mathrm{rpm}$. The extraction process was continued for $2 \mathrm{~h}$, the mixture was filtered, and the solvent was evaporated using an R-114 rotary evaporator Büchi (Barcelona, Spain). The resulting thiosulfinates content was determined by HPLC analyses, using the procedure described below.

\subsection{HPLC Analyses of Allium sativum Extract}

The thiosulfinate content of garlic was determined using a Shimadzu HPLC apparatus (Duisbrug, Germany), as outlined previously [43] using a methanol/water (50:50) mobile phase and a Supelcosil C18 $(150 \times 4.6 \mathrm{~mm}$, i.d. $=5 \mu \mathrm{m})$ stationary phase provided by Analisis Vinicos S.A. (Tomelloso, Spain). Solute detection was accomplished by using an UV-vis detector, set at $254 \mathrm{~nm}$. The mobile phase flow rate was $1 \mathrm{~mL} / \mathrm{min}$. Diallyl disulfide was used as internal standard. A typical composition of the compounds presented in the extract used in this study is shown in Table 1. We employed diallyl thiosulfinate (allicin) concentration as the reference for the elaboration of the experimental treatments.

\subsection{Cell Culture and Chemotherapy Drugs}

The human colorectal cancer cell lines Caco-2 and HT-29 were obtained from the American Type Culture Collection ([Caco2] ATCC ${ }^{\circledR}$ HTB-37 ${ }^{\mathrm{TM}}$ and [HT-29] ATCC ${ }^{\circledR}$ HTB-38 $\left.{ }^{\mathrm{TM}}\right)$. Cells were maintained in Dulbecco's Modified Eagle Medium (DMEM, Sigma Aldrich, Darmstadt, Germany), supplemented with $10 \%$ fetal bovine serum and antibiotics (penicillin $100 \mathrm{IU} / \mathrm{mL}$ and streptomycin $100 \mu \mathrm{g} / \mathrm{mL}$, Sigma Aldrich, Darmstadt, Germany). Cell cultures were kept at $37{ }^{\circ} \mathrm{C}$ in an atmosphere of $5 \%$ $\mathrm{CO}_{2}$. Chemotherapeutic drugs (5-FU and oxaliplatin) were obtained from Accord Healthcare S.L.U. (Barcelona, Spain).

\subsection{Cell Proliferation-Neutral Red Uptake}

The neutral red uptake assay provides a quantitative estimation of the number of viable cells in a culture. It is based on the ability of viable cells to incorporate and bind the supravital dye neutral red in the lysosomes. Caco-2 and HT-29 were seeded in 96-well tissue culture plates $\left(1 \times 10^{4}\right.$ cells/well), and the day after, cells were incubated for $24 \mathrm{~h}$ with different thiosulfinate-enriched Allium sativum extract concentrations (allicin ranging from 1 to $275 \mu \mathrm{g} / \mathrm{mL}$ ). The plates were then incubated for $2 \mathrm{~h}$ with DMEM medium containing $40 \mu \mathrm{g} / \mathrm{mL}$ neutral red (Sigma Aldrich, Darmstadt, Germany). The cells were subsequently washed with phosphate buffered saline and the retained dye was extracted with a solubilization solution (1\% glacial acetic acid, 50\% ethanol and 49\% distilled water) and the absorbance was read using a spectrophotometer (Dynex Spectra MR, Chantilly, VA, USA) at $540 \mathrm{~nm}$. 


\subsection{Cell Proliferation-Mitochondrial Activity (MTT)}

The (3-(4,5-Dimethylthiazol-2yl)-2,5-diphenyl-tetrazolium bromide) (MTT) assay estimates viable cells with active metabolism, that convert MTT into a purple colored formazan product. It was performed based on a previously described method, with slight modifications (20). Briefly, after exposure to the treatments (thiosulfinate-enriched Allium sativum extract and 5-FU/oxaliplatin), $100 \mu \mathrm{L}$ of $0.5 \mu \mathrm{g} / \mathrm{mL}$ MTT (Sigma-Aldrich, Darmstadt, Germany) was added to each well and further incubated in the dark at $37^{\circ} \mathrm{C}, 5 \% \mathrm{CO}_{2}$. After $4 \mathrm{~h}$, the medium was aspirated and $100 \mu \mathrm{L}$ of DMSO added to dissolve the formazan product. Plates were placed on a shaking incubator for $15 \mathrm{~min}$ and read at $570 \mathrm{~nm}$ by a microplate reader (Dynex Spectra MR, Chantilly, VA, USA). Each treatment was tested in sextuplicate and the whole experiment was repeated twice. Data were expressed as a percentage of viable cells referred to control cells treated with vehicle (complete DMEM).

\subsection{Cytotoxicity Assay —Lactate Dehydrogenase (LDH) Release}

CytoTox 96®Non-Radioactive Cytotoxicity Assay (Promega, Madison, WI, USA) measures lactate dehydrogenase (LDH), a stable cytosolic enzyme that is released upon cell lysis. It was only used to study the cytotoxicity of this thiosulfinate-enriched Allium sativum extract. Thus, $1 \times 10^{4}$ cells/well were seeded in 96-well plates, and the day after incubated for $24 \mathrm{~h}$ with different extract concentrations (allicin ranging from 1 to $275 \mu \mathrm{g} / \mathrm{mL}$ ). The activity of LDH was determined by the conversion of lactate to pyruvate and the subsequent reaction thereof with a tetrazolium salt to form formazan. Absorbances were measured with a spectrophotometer (Dynex Spectra MR, Chantilly, VA, USA) at $490 \mathrm{~nm}$ and were proportional to the number of damaged cells in the culture. Two independent experiments were performed with six replicates for each condition (cell type and concentration).

\subsection{Morphology Analysis—Optical Microscopy Images}

The effect of the thiosulfinate-enriched Allium sativum extract on cell morphology after $24 \mathrm{~h}$ of incubation was studied by optical microscopy. HT-29 morphology was imaged by optical microscopy using a Nikon ECLIPSE Ti-U microscope (Tokyo, Japan) at 10x, before the corresponding cell proliferation assay (Supplementary Figure S1).

\subsection{Apoptosis Assay-TUNEL Method}

The effect of different thiosulfinate-enriched Allium sativum extract concentrations on cell fate after $24 \mathrm{~h}$ incubation was studied by the ApopTag ${ }^{\circledR}$ Fluorescein Direct In Situ Apoptosis Detection Kit (Sigma-Aldrich, Darmstadt, Germany), which detects apoptotic cells in situ by the direct TUNEL method. The functional state of HT-29 cells was analyzed by flow cytometry following the manufacturer's instructions (Table 2). At least 5000 events were acquired in a FACScan cytometer (Becton Dickinson, Franklin Lakes, NJ, USA) and analyzed using the CellQuest ${ }^{\mathrm{TM}}$ Pro software (Becton Dickinson, Franklin Lakes, NJ, USA).

\subsection{Statistical Analysis}

The GraphPad PRISM software 4.0 (San Diego, CA, USA) was used for the statistical analysis. Comparisons between two experimental groups were performed with Student $t$-tests. Statistical significance was considered at the 0.05 level.

\section{Conclusions}

Our results suggest that, as a consequence of the co-administration of thiosulfinate-enriched Allium sativum extract with lower doses of the chemotherapeutic agents, a similar anti-proliferative effect to that when chemotherapy drugs are administered alone could be achieved, at higher doses, so that a reduction in toxic side-effects could be elicited. Moreover, our financial analysis also highlights the potential economic savings of a combined treatment using the thiosulfinate-enriched Allium sativum 
extract as a coadjuvant for chemotherapy, pointing it out as a promising natural product and functional food for treating tumoral cells.

\section{Patents}

Patent WO 2008/102036 A1. Method for obtaining a freeze-dried, stable extract from plants of the Allium genus.

National patent (Spanish Trademark number ES2675282A1). Allium sativum extract, its use for the manufacture of a medicinal product for the treatment of diseases, and its obtaining procedure.

Supplementary Materials: Supplementary Materials can be found at http://www.mdpi.com/1422-0067/21/8/2766/ s1.

Author Contributions: J.M.P.-O.: Conceptualization, Methodology, Investigation, Writing-Original draft preparation, Writing-Reviewing and editing. E.M.G.-M.: Methodology, Investigation. M.A.d.l.C.-M.: Investigation, Visualization. J.F.R.: Resources, Supervision. I.G.: Resources, Supervision. M.T.G.: Visualization, Writing-Reviewing and Editing. F.J.R.-C.: Resources, Supervision, Funding acquisition. All authors have read and agreed to the published version of the manuscript.

Funding: M.A.d.l.C.-M. is funded by the Government of Castilla-La Mancha through 'Convocatoria de Ayudas para la incorporación de investigadores', Ref. II-2016_06. E.M.G.-M. is funded by the implementation research program of the UCLM (UCLM resolution date: 31/07/2014), with a contract for accessing the Spanish System of Science, Technology and Innovation-Secti (co-funded by the European Commission/FSE funds). J.M.P.-O. is funded by the European regional development fund (Castilla-La Mancha FEDER 2014-20 PO).

Acknowledgments: The authors would like to thank Daniel Alcazar, David Gallego and Felipe Pardo for their work on this project during their university internships.

Conflicts of Interest: I.G. is part of the authors of the registered brand Aliben(C) (European Trade mark number 10543429) which entitles the lyophilized Allium sativum extract employed in this study (patent WO 2008/102036 A1. Method for obtaining a freeze-dried, stable extract from plants of the Allium genus). All authors, except M.A.d.l.C.-M. and M.T.G., are co-contributors of a national registered patent (Spanish Trade mark number ES2675282A1), which employs the lyophilized Allium sativum extract, its use for the manufacture of a medicinal product for the treatment of diseases, and its obtaining procedure.

\section{Abbreviations}

$\begin{array}{ll}\text { 5-FU } & \text { 5-fluorouracil } \\ \text { MTT } & \text { 3-(4,5-Dimethylthiazol-2-yl)-2,5-Diphenyltetrazolium bromide } \\ \text { LDH } & \text { lactate dehydrogenase } \\ \text { NP } & \text { natural products } \\ \text { HPLC } & \text { high-performance liquid chromatography } \\ \text { UV-vis } & \text { ultraviolet-visible } \\ \text { DMEM } & \text { Dulbecco's modified Eagle medium } \\ \text { VAT } & \text { value added tax }\end{array}$

\section{References}

1. Guo, M.; Song, W. The growing U.S. bioeconomy: Drivers, development and constraints. New Biotechnol. 2019, 49, 48-57. [CrossRef] [PubMed]

2. Dias, D.A.; Urban, S.; Roessner, U. A historical overview of natural products in drug discovery. Metabolites 2012, 2, 303-336. [CrossRef] [PubMed]

3. John, J.E. Natural products-Based drugs and membrane permeability, a hypothesis. Chem. Biol. Drug Des. 2009, 73, 367-368. [CrossRef]

4. Butler, M.S. The role of natural product chemistry in drug discovery. J. Nat. Prod. 2004, 67, $2141-2153$. [CrossRef] [PubMed]

5. Chen, J.; Li, W.; Yao, H.; Xu, J. Insights into drug discovery from natural products through structural modification. Fitoterapia 2015, 103, 231-241. [CrossRef] [PubMed]

6. Block, E. The chemistry of garlic and onions. Sci. Am. 1985, 252, 114-119. [CrossRef]

7. Rana, S.V.; Pal, R.; Vaiphei, K.; Sharma, S.K.; Ola, R.P. Garlic in health and disease. Nutr. Res. Rev. 2011, 24, 60-71. [CrossRef] 
8. Shang, A.; Cao, S.Y.; Xu, X.Y.; Gan, R.Y.; Tang, G.Y.; Corke, H.; Mavumengwana, V.; Li, H.B. Bioactive Compounds and Biological Functions of Garlic (Allium sativum L.). Foods 2019, 8, 246. [CrossRef]

9. Borlinghaus, J.; Albrecht, F.; Gruhlke, M.C.H.; Nwachukwu, I.D.; Slusarenko, A.J. Allicin: Chemistry and Biological Properties. Molecules 2014, 19, 12591-12618. [CrossRef]

10. Li, M.; Ciu, J.R.; Ye, Y.; Min, J.M.; Zhang, L.H.; Wang, K.; Gares, M.; Cros, J.; Wright, M.; Leung-Tack, J. Antitumor activity of Z-ajoene, a natural compound purified from garlic: Antimitotic and microtubule-interaction properties. Carcinogenesis 2002, 23, 573-579. [CrossRef]

11. Iberl, B.; Winkler, G.; Knobloch, K. Products of Allicin Transformation: Ajoenes and Dithiins, Characterization and their Determination by HPLC*. Planta Med. 1990, 56, 202-211. [CrossRef] [PubMed]

12. Krest, I.; Keusgen, M. Quality of herbal remedies from Allium sativum: Differences between alliinase from garlic powder and fresh garlic. Planta Med. 1999, 65, 139-143. [CrossRef] [PubMed]

13. Cañizares, P.; Gracia, I.; Gómez, L.A.; Martín de Argila, C.; Boixeda, D.; García, A.; de Rafael, L. Allyl-Thiosulfinates, the bacteriostatic compounds of garlic against Helicobacter pylori. Biotechnol. Prog. 2004, 20, 397-401. [CrossRef] [PubMed]

14. Cañizares, P.; Gracia, I.; Gómez, L.A.; García, A.; Martín De Argila, C.; Boixeda, D.; de Rafael, L. Thermal degradation of allicin in garlic extracts and its implication on the inhibition of the in-Vitro growth of Helicobacter pylori. Biotechnol. Prog. 2004, 20, 32-37. [CrossRef]

15. Lawson, L.D.; Wang, Z.J.; Hughes, B.G. Identification and HPLC quantitation of the sulfides and dialk(en)yl thiosulfinates in commercial garlic products. Planta Med. 1991, 57, 363-370. [CrossRef]

16. Staba, E.J.; Lash, L.; Staba, J.E. A commentary on the effects of garlic extraction and formulation on product composition. J. Nutr. 2001, 131, 1118S-1119S. [CrossRef]

17. Rahman, K. Historical perspective on garlic and cardiovascular disease. J. Nutr. 2001, 131, 977S-979S. [CrossRef]

18. Sivam, G.P. Protection against Helicobacter pylori and other bacterial infections by garlic. J. Nutr. 2001, 131, 1106S-1108S. [CrossRef]

19. Galceran, J.; Ameijide, A.; Carulla, M.; Mateos, A.; Quiros, J.R.; Rojas, D.; Aleman, A.; Torrella, A.; Chico, M.; Vicente, M.; et al. Cancer incidence in Spain, 2015. Clin. Transl. Oncol. 2017, 19, 799-825. [CrossRef]

20. Bat-Chen, W.; Golan, T.; Peri, I.; Ludmer, Z.; Schwartz, B. Allicin Purified From Fresh Garlic Cloves Induces Apoptosis in Colon Cancer Cells Via Nrf2. Nutr. Cancer 2010, 62, 947-957. [CrossRef]

21. Jakubíková, J.; Sedlák, J. Garlic-Derived organosulfides induce cytotoxicity, apoptosis, cell cycle arrest and oxidative stress in human colon carcinoma cell lines. Neoplasma 2006, 53, 191-199. [PubMed]

22. Siegers, C.P.; Steffen, B.; Röbke, A.; Pentz, R. The effects of garlic preparations against human tumor cell proliferation. Phytomed. Int. J. Phytother. Phytopharm. 1999, 6, 7-11. [CrossRef]

23. Rajput, S.; Mandal, M. Antitumor promoting potential of selected phytochemicals derived from spices: A review. Eur. J. Cancer Prev. Off. J. Eur. Cancer Prev. Organ. (ECP) 2012, 21, 205-215. [CrossRef] [PubMed]

24. Pinto, J.T.; Rivlin, R.S. Antiproliferative effects of allium derivatives from garlic. J. Nutr. 2001, 131, 1058S-1060S. [CrossRef]

25. Hirsch, K.; Danilenko, M.; Giat, J.; Miron, T.; Rabinkov, A.; Wilchek, M.; Mirelman, D.; Levy, J.; Sharoni, Y. Effect of purified allicin, the major ingredient of freshly crushed garlic, on cancer cell proliferation. Nutr. Cancer 2000, 38, 245-254. [CrossRef]

26. Milner, J.A. Garlic: Its anticarcinogenic and antitumorigenic properties. Nutr. Rev. 1996, 54, S82-S86. [CrossRef]

27. Almatroodi, S.A.; Alsahli, M.A.; Almatroudi, A.; Rahmani, A.H. Garlic and its Active Compounds: A Potential Candidate in The Prevention of Cancer by Modulating Various Cell Signalling Pathways. Anti-Cancer Agents Med. Chem. 2019, 19, 1314-1324. [CrossRef]

28. Chhabria, S.V.; Akbarsha, M.A.; Li, A.P.; Kharkar, P.S.; Desai, K.B. In situ allicin generation using targeted alliinase delivery for inhibition of MIA PaCa-2 cells via epigenetic changes, oxidative stress and cyclin-Dependent kinase inhibitor (CDKI) expression. Apoptosis Int. J. Program. Cell Death 2015, 20, 1388-1409. [CrossRef]

29. Li, C.; Jing, H.; Ma, G.; Liang, P. Allicin induces apoptosis through activation of both intrinsic and extrinsic pathways in glioma cells. Mol. Med. Rep. 2018, 17, 5976-5981. [CrossRef]

30. Zhuang, J.; Li, Y.; Chi, Y. Role of p38 MAPK activation and mitochondrial cytochrome-c release in allicin-Induced apoptosis in SK-N-SH cells. Anti-Cancer Drugs 2016, 27, 312-317. [CrossRef] 
31. Cha, J.H.; Choi, Y.J.; Cha, S.H.; Choi, C.H.; Cho, W.H. Allicin inhibits cell growth and induces apoptosis in U87MG human glioblastoma cells through an ERK-dependent pathway. Oncol. Rep. 2012, 28, 41-48. [CrossRef] [PubMed]

32. Zhang, W.; Ha, M.; Gong, Y.; Xu, Y.; Dong, N.; Yuan, Y. Allicin induces apoptosis in gastric cancer cells through activation of both extrinsic and intrinsic pathways. Oncol. Rep. 2010, 24, 1585-1592. [PubMed]

33. Miron, T.; Wilchek, M.; Sharp, A.; Nakagawa, Y.; Naoi, M.; Nozawa, Y.; Akao, Y. Allicin inhibits cell growth and induces apoptosis through the mitochondrial pathway in HL60 and U937 cells. J. Nutr. Biochem. 2008, 19,524-535. [CrossRef] [PubMed]

34. Oommen, S.; Anto, R.J.; Srinivas, G.; Karunagaran, D. Allicin (from garlic) induces caspase-mediated apoptosis in cancer cells. Eur. J. Pharmacol. 2004, 485, 97-103. [CrossRef]

35. Lea, M.A.; Rasheed, M.; Randolph, V.M.; Khan, F.; Shareef, A.; desBordes, C. Induction of histone acetylation and inhibition of growth of mouse erythroleukemia cells by S-allylmercaptocysteine. Nutr. Cancer 2002, 43, 90-102. [CrossRef]

36. Block, E.; Bechand, B.; Gundala, S.; Vattekkatte, A.; Wang, K.; Mousa, S.S.; Godugu, K.; Yalcin, M.; Mousa, S.A. Fluorinated Analog NMR s of Organosulfur Compounds from Garlic (Allium sativum): Synthesis, Chemistry and Anti-Angiogenesis and Antithrombotic Studies. Molecules 2017, 22, 2081. [CrossRef]

37. Park, S.-Y.; Cho, S.-J.; Kwon, H.-C.; Lee, K.-R.; Rhee, D.-K.; Pyo, S. Caspase-Independent cell death by allicin in human epithelial carcinoma cells: Involvement of PKA. Cancer Lett. 2005, 224, 123-132. [CrossRef]

38. Antony, M.L.; Singh, S.V. Molecular mechanisms and targets of cancer chemoprevention by garlic-derived bioactive compound diallyl trisulfide. Indian J. Exp. Biol. 2011, 49, 805-816.

39. Rejhova, A.; Opattova, A.; Cumova, A.; Sliva, D.; Vodicka, P. Natural compounds and combination therapy in colorectal cancer treatment. Eur. J. Med. Chem. 2018, 144, 582-594. [CrossRef]

40. Redondo-Blanco, S.; Fernandez, J.; Gutierrez-Del-Rio, I.; Villar, C.J.; Lombo, F. New Insights toward Colorectal Cancer Chemotherapy Using Natural Bioactive Compounds. Front. Pharmacol. 2017, 8, 109. [CrossRef] [PubMed]

41. Nobili, S.; Lippi, D.; Witort, E.; Donnini, M.; Bausi, L.; Mini, E.; Capaccioli, S. Natural compounds for cancer treatment and prevention. Pharmacol. Res. 2009, 59, 365-378. [CrossRef] [PubMed]

42. Aggarwal, B.B.; Takada, Y.; Oommen, O.V. From chemoprevention to chemotherapy: Common targets and common goals. Expert Opin. Investig. Drugs 2004, 13, 1327-1338. [CrossRef] [PubMed]

43. Cañizares, P.; Gracia, I.; Gómez, L.A.; Martín de Argila, C.; de Rafael, L.; García, A. Optimization of Allium sativum solvent extraction for the inhibition of in vitro growth of Helicobacter pylori. Biotechnol. Prog. 2002, 18, 1227-1232. [CrossRef] [PubMed]

(C) 2020 by the authors. Licensee MDPI, Basel, Switzerland. This article is an open access article distributed under the terms and conditions of the Creative Commons Attribution (CC BY) license (http://creativecommons.org/licenses/by/4.0/). 